\title{
PIONEERING in vitro STUDIES FOR CALLUS FORMATION OF Colchicum chalcedonicum Azn.
}

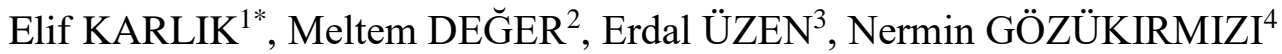 \\ 1 İstinye University, Department of Molecular Biology and Genetics, İstanbul, TURKEY \\ ${ }^{2}$ HAN University of Applied Sciences, Department of Life Science, Nijmegen, NETHERLANDS \\ ${ }^{3}$ İstanbul University, Faculty of Sciences, Department of Biology, İstanbul, TURKEY \\ ${ }^{4}$ İstanbul University, Faculty of Sciences, Department of Molecular Biology and Genetics, İstanbul, TURKEY
}

Cite this article as:

Karlık E., Değer, M., Üzen E., Gözükırmızı N. 2020. Pioneering in vitro Studies for Callus Formation of Colchicum chalcedonicum Azn. Trakya Univ J Nat Sci, 21(2): 131-137, DOI: 10.23902/trkjnat.776974

Edited by:

Mykyta Peregrym

*Corresponding Author: Elif Karlık

elif.karlik@istinye.edu.tr

\section{ORCID ID:}

orcid.org/0000-0003-0669-2725

Key words:

Colchicum chalcedonicum

Tissue culture

Callus formation

Conservation

\begin{abstract}
Colchicum calcedonicum Azn is one of the endemic species distributed in Turkey, where many endemic plant species occur. It has long-oval shaped corm under the soil, and usually 3-4 leaves on it. In vitro production of endemic species using callus culture has become promising study for conservation. The aim of this study is to generate an efficient callus protocol for in vitro production of $C$. chalcedonicum. To sterilize the explants, $0.25 \%(\mathrm{w} / \mathrm{v})$ mercuric chloride $\left(\mathrm{HgCl}_{2}\right)$ was used for $20 \mathrm{~min}$. In addition to mercuric chloride, surface sterilization was conducted by using $6.5 \% \mathrm{NaCl}$ with Tween 80 for $30 \mathrm{~min}$. We used 19 different mediums and the primary callus formation was obtained in Murashige \& Skoog's basal medium (MS) supplemented with 2,4-D (2 $\left.\mathrm{mg} \mathrm{L}^{-1}\right), 2 \mathrm{IP}\left(0.5 \mathrm{mg} \mathrm{L}^{-1}\right), 3 \%$ sucrose and $0.05 \%$ active carbon. Our study demonstrated the active carbon usage was effective for the primary callus formation. This study is the first report for primary callus formation of $C$. chalcedonicum. However, our work is a pioneering study to improve callus formation protocol system for in vitro conservation of endemic species $C$. chalcedonicum.
\end{abstract}

Özet: Colchicum calcedonicum Azn, pek çok endemik bitki türünün görüldüğü Türkiye'de yayılış gösteren endemik türlerden biridir. Toprak altında uzun-oval şekilli soğanı ile genellikle 3-4 yapraklıdır. Kallus kültürü kullanarak endemik türlerin in vitro üretimi, bu türlerin korunmasında umut verici bir çalışma haline gelmiştir. Bu çalışmanın amacı, in vitro C. chalcedonicum üretimi için verimli kallus protokolünün oluşturulabilmesidir. Explantların sterilizasyonunda, $20 \mathrm{dk} \% 0.25$ (w/v) cıva klorür $\left(\mathrm{HgCl}_{2}\right)$ kullanılmıştır. Cıva klorüre ilaveten, yüzey sterilizasyonunda $30 \mathrm{dk}$ boyunca Tween $80, \% 6,5 \mathrm{NaCl}$ ile birlikte kullanılmıştır. Bu çalışmada, 19 farklı besiyeri kullanılmış olup primer kallus oluşumu 2,4-D (2 mg L-1), 2IP (0,5 mg L-1), \%3 sükroz ve \%0,05 aktif karbon içeren Murashige \& Skoog bazal besiyerinde elde edilmiştir. Çalışmamız, aktif karbon kullanımının primer kallus oluşumunda etkili olduğunu göstermiştir. $\mathrm{Bu}$ çalışma, $\mathrm{C}$. chalcedonicum'un primer kallus oluşumu için ilk rapordur. Bununla birlikte, çalışmamız endemik tür olan C. chalcedonicum'un in vitro korunması ve kallus oluşum protokolünün geliştirilmesinde öncü bir çalışmadır.

\section{Introduction}

The genus Colchicum L. within the family Colchicaceae have been known for more than 2000 years for their marked beneficial and poisonous effects (Brickell 1984). In Turkey, 50 Colchicum species were described of which 15 are endemic. Their limited distribution at a very high altitude and the restricted period of growth are the reasons for the low yield of members of the genus. Colchicum includes about 200 perennial flowering species growing from corms and their ovary flowers form underground. The important species of the genus, C. luteum Baker and C. autumnale L. contain 0.2-

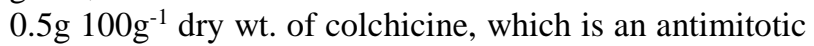
agent by preventing accumulation of microtubules and inhibiting the cell division in the metaphase (The Wealth of India 1962, Kapadia et al. 1972, Dumontet \& Sikic 1999, Combeau et al. 2000, Pirildar et al. 2010).

Colchicum chalcedonicum Azn., which is also known as Kadıköy (Chalcedon) crocus, is one of the endemic species of Colchicaceae in Turkey. Colchicum chalcedonicum was collected in Kadıköy in İstanbul by Aznavour in 1897 (Aznavour 1897). It has usually 4 leaves and long-oval shaped corms under the soil. Their chromosome number is $2 \mathrm{n}=50$. The plant grows in rich red soils in dry stony and rocky places. They are also found on rare peaks and shrubs. Colchicum 
chalcedonium flowers from August to September, being out of leaves and fruits from February to April. Additionally, the plants only live underground for a part of the year, thus in vivo and in vitro micro-propagation and in vitro culture of this species are difficult making the species to be known as calcitrant (Brickell 1984, Persson 1988, 1998, 1999a, 1999b, 1999c, 2000, 2001, 2007, Akan \& Eker 2005).

Several studies reported on production of colchicine alkaloid by plant tissue cultures (Hayashi et al. 1988, Yoshida et al. 1988). Callus tissues were first induced from flowering shoots of C. autumnale L. by using MS (Murashige \& Skoog 1962) containing 2,4Dichlorophenoxyacetic acid (2,4-D), while colchicine from callus tissue was produced by MS with indole butyric acid (IBA) and kinetin (Hayashi et al. 1988). Daradkeh et al. (2012) used C. hierosolymitanum Feinbrun for callus production on MS supplemented with $0.45 \mu \mathrm{M} 2$, 4-dichlorophenoxyacetic acid under dark conditions. To induce colchicine production, callus was sub-cultured every 27 days on the same liquid media supplemented with $0.54 \mu \mathrm{M} 1$ - naphthaleneacetic acid. The researchers observed that higher cell fresh weight was resulted with $9 \mu \mathrm{M}$ 6-benzyladenine with $0.45 \mu \mathrm{M} 2$, 4dichlorophenoxyacetic acid. Additionally, the highest colchicine alkaloid $\left(0.090 \mathrm{mg} \mathrm{g}^{-1} \mathrm{DW}\right)$ was obtained at 0.1 $\mathrm{M}$ sucrose after 4 weeks incubation (Daradkeh et al. 2012). Different parts of C. chalcedonicum and C. micranthum Boiss., which are endemic for Turkey, were also investigated for cytotoxic activities for future medical approaches. Daradkeh et al. (2012) managed to isolate colchicine, colchifoline, 2-demethylcolchicine, demecolcine, 4-hydroxycolchicine and $N$-deacetyl- $N$ formylcolchicine which showed high cytotoxicity. The main alkaloids of these two Colchicum species were found as colchicine and colchifoline. According to the results of this study, the greatest diversity in tropolone alkaloids were found in the seed of $C$. chalcedonicum (Gulsoy-Toplan et al. 2018). Despite its importance, no systematic attempt has been performed for mass propagation of $C$. chalcedonicum. The restricted distribution of this endemic plant has endangered its survival. Therefore, tissue culture approaches are required to get rapid propagation as in vitro protocol for micro-propagation, but there is no a practical protocol available for in vitro mass propagation of $C$. chalcedonicum. In the present study, we report the first and efficient protocol for callus generation of $C$. chalcedonicum using corms.

\section{Materials and Methods}

\section{Field Studies and the Plant Material}

Colchicum chalcedonicum corms used in this study were kindly provided by Erdal Uzen from Kadıköy. Field studies were performed from April 2017 to November 2017 at Çamlıca Hill (Ferah neighbourhood) (Fig. 1). The specimen was obtained from seed, leave, and corm during seeding, blooming and fruit time of $C$. chalcedonicum (Fig. 2). The specimens are deposited in the Istanbul University Alfred Heilbronn Botanical Garden.

Corms were long-ovaloid like egg-shaped, and corm shells mostly with several layers, the outer coriaceous and dark brown, the inner thin and reddish-brown. Leaves were 3-4, hysteranthous, patent, and oblong-lanceolate, light or dark-green hereinbefore mentioned by Küçüker (1984).

\section{Explant Preparation}

The fresh corms, leaves and corm shells were used as explants. The explants were excised aseptically with sterile scissors and washed with running tap water for 30 minutes, washed with $\mathrm{dH}_{2} \mathrm{O}$ for three times for $5 \mathrm{~min}$. The explants were then sterilized with $0.25 \%(\mathrm{w} / \mathrm{v})$ mercuric chloride $\left(\mathrm{HgCl}_{2}\right)$ solution for $20 \mathrm{~min}$. followed by surface sterilization with $6.5 \% \mathrm{NaCl}$ with Tween 80 for 30 min. Then, the explants were rinsed thoroughly with sterile $\mathrm{dH}_{2} \mathrm{O}$ for three times for $5 \mathrm{~min}$. followed by $70 \%$ ethanol for $10 \mathrm{~min}$. The explants were again washed with $\mathrm{dH}_{2} \mathrm{O}$ three times and blotted dry on sterilized filter paper. Finally, ten sterilized explants were aseptically placed on tissue culture mediums.

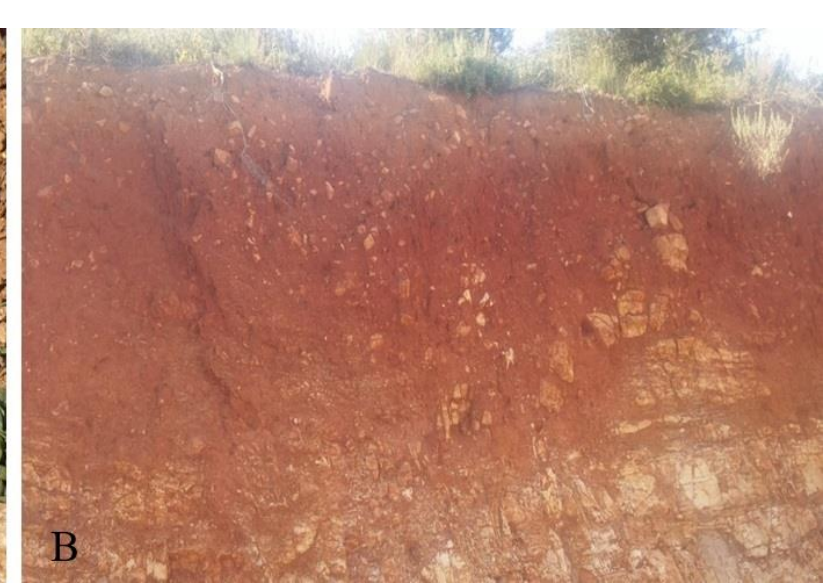

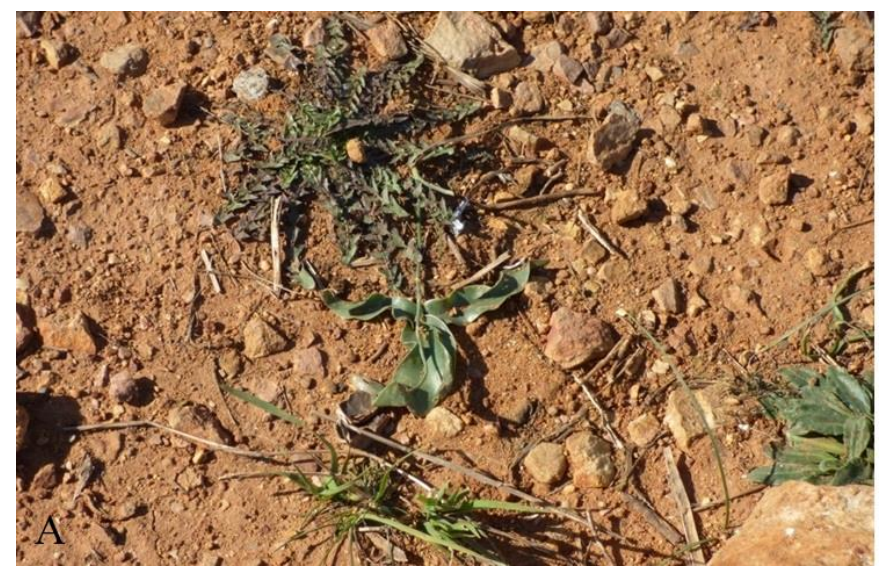

Fig. 1. The red and iron-rich Terra Rosa soil at Çamlıca Hill where C. chalcedonicum specimens were found during the study. 

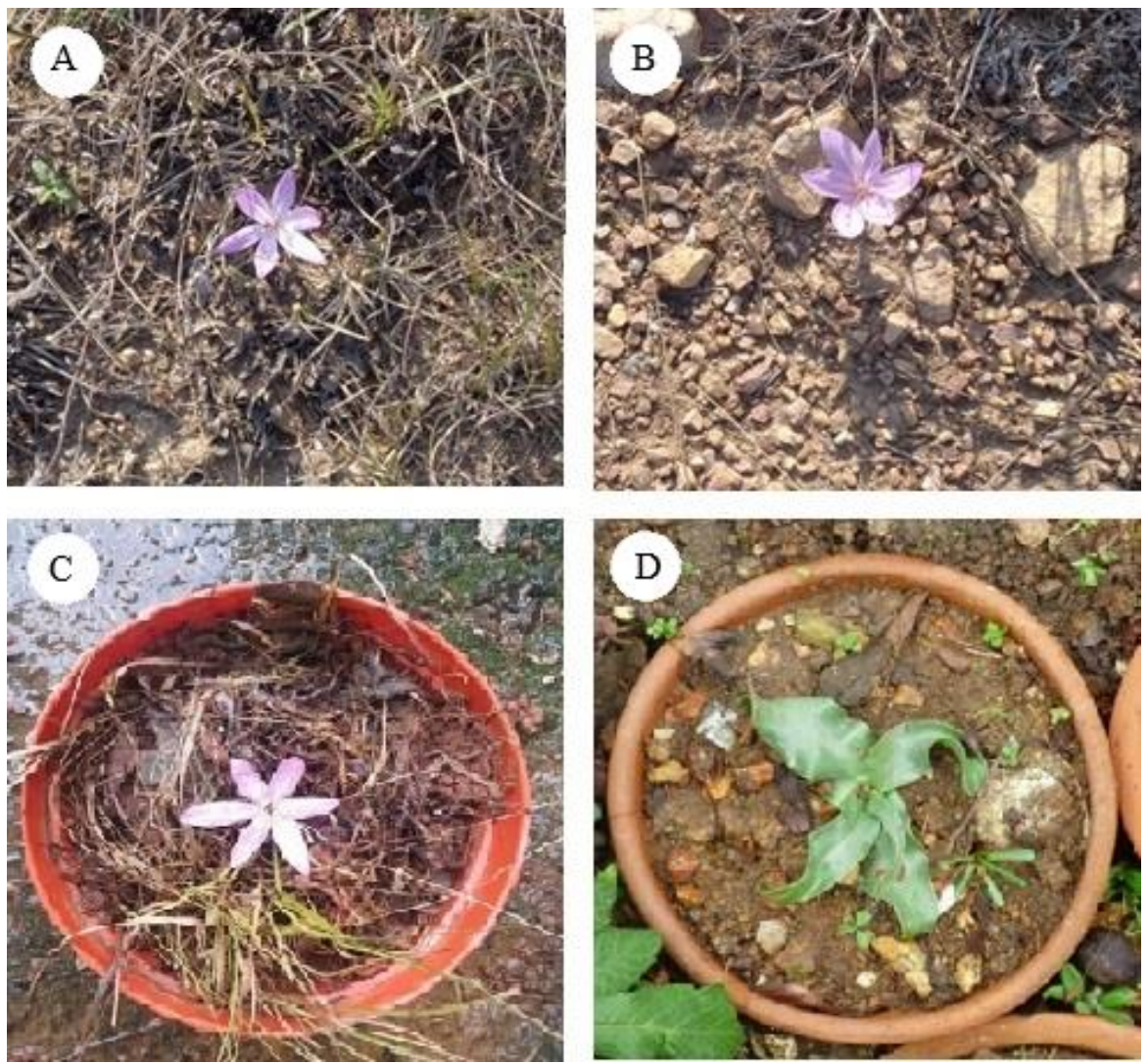

Fig. 2. The natural appearance of C. chalcedonicum' in field studies (A and B) and in The Istanbul University Alfred Heilbronn Botanical Garden (C and D).

\section{Inoculation and Incubation}

The disinfected explants were cultured on MS medium (Murashige \& Skoog 1962) supplemented with different concentrations and combinations of sucrose and plant growth regulators (PGRs) [1-Naphthalene acetic acid (NAA), 6-Benzylaminopurine (BAP), Zeatin (ZEA), 2,4Dichlorophenoxy acetic acid (2,4-D) and 6- $(\gamma, \gamma-$ Dimethylallylamino) purine (2IP)]. To induce callus induction, all cultures were maintained in a growth chamber for two weeks to several months at $18-25 \pm 2.0^{\circ} \mathrm{C}$ with dark according to used medium. After callus induction, the cultures were sub-cultured at $18-25 \pm 2.0^{\circ} \mathrm{C}$ with the light intensity of $75 \mu \mathrm{mol} \mathrm{m} \mathrm{m}^{-2} \mathrm{~s}^{-1}$ provided by cool white fluorescent lamps for a photoperiod of 16:8 hours of light and dark period in every 24-hour cycle. Relative humidity of the growth chamber was kept at $50 \%$. Active carbon was also used for development of callus. MS medium was prepared with some modifications. The $\mathrm{pH}$ of the media was first adjusted to 5.8, then it was autoclaved for $15 \mathrm{~min}$ at $121^{\circ} \mathrm{C}$. As the control group, MS medium supplemented with $2 \%$ Sucrose (Suc) were used. The explants were cultured on MS medium supplemented with 3, 8 and 10\% (w/v) Suc and various plant growth regulators. For initiating callus, different treatment combinations including 2,4-D as an auxin $\left(2 \mathrm{mg} \mathrm{ml}^{-1}\right)$ and BAP as a cytokinin $\left(0.5 \mathrm{mg} \mathrm{ml}^{-1}\right)$; NAA $\left(1 \mathrm{mg} \mathrm{ml}^{-1}\right)$ and ZEA $\left(1 \mathrm{mg} \mathrm{ml}^{-1}\right)$; NAA $\left(2 \mathrm{mg} \mathrm{ml}^{-1}\right)$ and BAP $\left(0.5 \mathrm{mg} \mathrm{ml}^{-}\right.$ $\left.{ }^{1}\right) ; 2,4 \mathrm{D}\left(2 \mathrm{mg} \mathrm{ml}^{-1}\right)$ and BAP $\left(0.5 \mathrm{mg} \mathrm{ml}^{-1}\right) ; 2,4 \mathrm{D}(2 \mathrm{mg}$ $\left.\mathrm{ml}^{-1}\right)$ and ZEA $\left(1 \mathrm{mg} \mathrm{ml}^{-1}\right) ; 2,4 \mathrm{D}\left(2 \mathrm{mg} \mathrm{ml}^{-1}\right)$, ZEA $(1 \mathrm{mg}$ $\left.\mathrm{ml}^{-1}\right)$ and BAP $\left(0.5 \mathrm{mg} \mathrm{ml}^{-1}\right) ; 2,4 \mathrm{D}\left(2 \mathrm{mg} \mathrm{ml}^{-1}\right)$ and 2IP $\left(0.5 \mathrm{mg} \mathrm{ml}^{-1}\right)$ were applied to the corm slices as three replicates. The last medium was applied as $2^{-1}$ MS supplemented with $2,4 \mathrm{D}\left(2 \mathrm{mg} \mathrm{ml}^{-1}\right)$, 2IP $\left(0.5 \mathrm{mg} \mathrm{ml}^{-1}\right)$, $3 \%$ Suc and $0.05 \%$ active carbon according to the report of Yalcin Mendi et al. (2017).

\section{Results}

Various explant types, PGRs, different sugar concentrations, and chemicals were tested for callus induction in $C$. chalcedonicum. Callus were only formed from corms (see Fig. 3). Leaves and corm shells as explant demonstrated no development for callus formation. Different researchers used different sterilization protocols which included different concentrations and combinations of $\mathrm{NaOCl}, \mathrm{NaCl}, \mathrm{HgCl}_{2}$, Tween 20 and Tween 80 (Khan et al. 2011, Daradkeh et al. 2012, Wagh et al. 2015). In our sterilization protocol, we observed $0.25 \%(\mathrm{w} / \mathrm{v})$ mercuric chloride $\left(\mathrm{HgCl}_{2}\right)$ and $6.5 \% \mathrm{NaCl}$ with Tween 80 were required to sterile $C$. chalcedonicum corms. However, $\mathrm{NaOCl}$ is not necessary for sterilization of $C$. chalcedonicum corms.

After determination of the sterilization protocol, different sucrose concentrations were tested. At the first step, two sucrose concentrations ( $3 \%$ and $8 \%$ ) were tested for all different PGRs combinations. Corms on $8 \%$ sucrose were formed as green and soft callus. Callus formation in 3\% sucrose was found to be slower than $8 \%$ sucrose, thus corms in $3 \%$ sucrose were transferred to 
mediums containing $10 \%$ sucrose to enhance callus formation.

Callus development was observed within a week after transferring medium to MS supplemented with NAA (1 $\left.\mathrm{mg} \mathrm{ml}^{-1}\right)$, ZEA $\left(1 \mathrm{mg} \mathrm{ml}^{-1}\right)$ and $10 \%$ Suc, becoming partly green and soft. Callus formation ratio in this media was around $15 \%$. Additionally, callus formation was observed on $2^{-1} \mathrm{MS}$ supplemented with 2,4 D $\left(2 \mathrm{mg} \mathrm{ml}^{-1}\right)$, 2IP $(0.5$ $\mathrm{mg} \mathrm{ml}^{-1}$ ), $3 \%$ Suc and $0.05 \%$ active carbon (see in Fig. 4). In this medium, callus formation ratio was around $75 \%$.
However, some cultures were transferred to $2^{-1} \mathrm{MS}$ supplemented with 2,4 D $\left(2 \mathrm{mg} \mathrm{ml}^{-1}\right), 2 \mathrm{IP}\left(0.5 \mathrm{mg} \mathrm{ml}^{-1}\right)$, $3 \%$ Suc, $0.05 \%$ active carbon medium after twelve weeks and the corms were observed to get a green colour and swelling. Eventually, after testing different PGRs and sugar concentrations, callus formations were only observed on MS supplemented with NAA (1 mg ml-1), ZEA $\left(1 \mathrm{mg} \mathrm{ml}^{-1}\right)$ containing different concentration of sucrose $-\% 8$ and $10 \%$ Suc- and $2^{-1}$ MS supplemented with 2,4 $\mathrm{D}\left(2 \mathrm{mg} \mathrm{ml}^{-1}\right), 2 \mathrm{IP}\left(0.5 \mathrm{mg} \mathrm{ml}^{-1}\right), 3 \%$ sucrose, $0.05 \%$ active carbon medium.

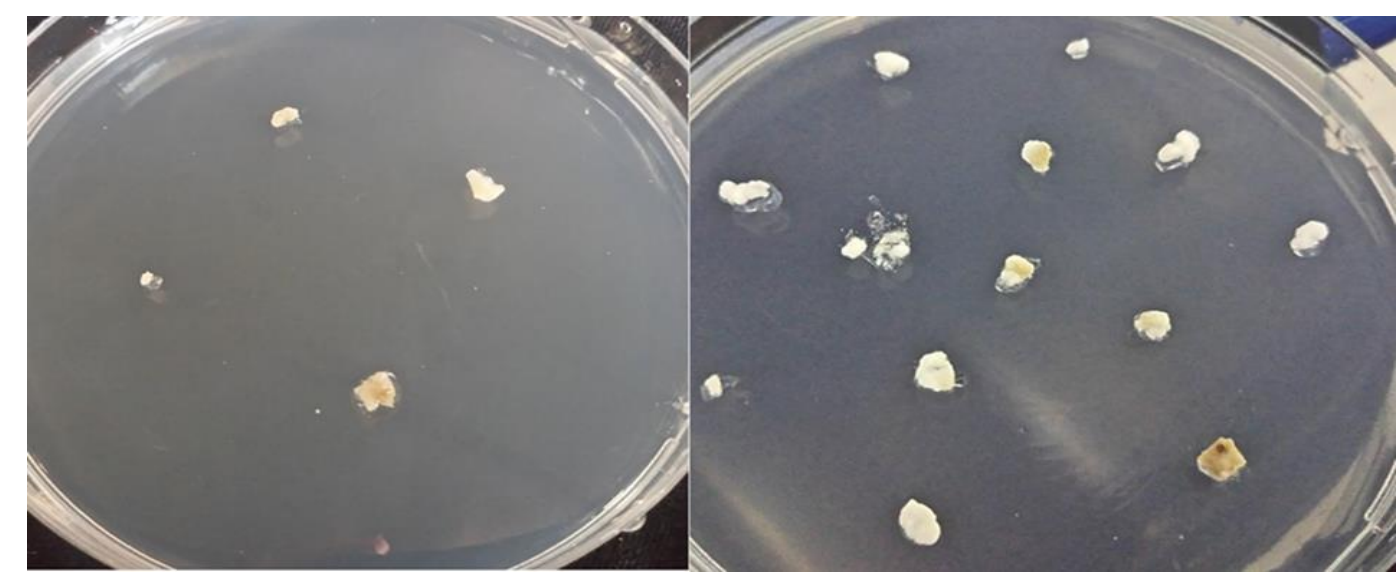

Fig. 3. Callus formation of $C$. chalcedonicum on [ZEA $\left(1 \mathrm{mg} \mathrm{ml}^{-1}\right)+\mathrm{NAA}\left(1 \mathrm{mg} \mathrm{ml}^{-1}\right)+10 \%$ Suc + MS basal medium]

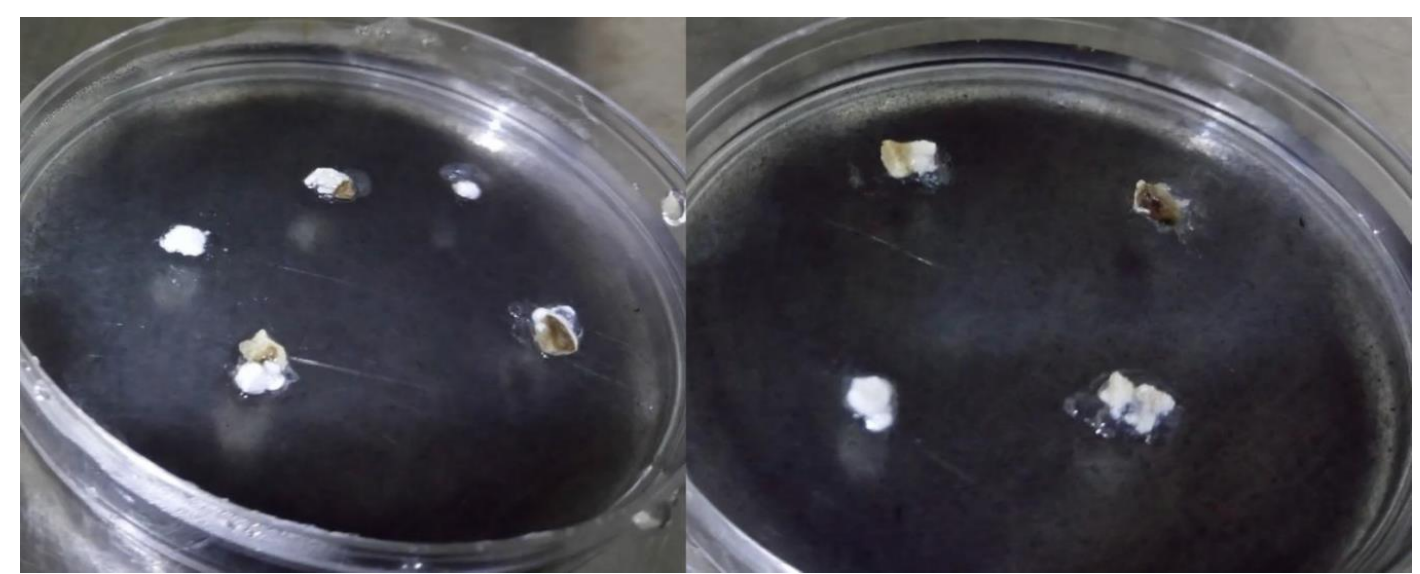

Fig. 4. Callus formation of $C$. chalcedonicum on $\left[2,4-\mathrm{D}\left(2 \mathrm{mg} \mathrm{L}^{-1}\right)+2 \mathrm{IP}\left(0.5 \mathrm{mg} \mathrm{L}^{-1}\right)+3 \%\right.$ Suc $+0.05 \%$ active carbon $+2^{-1} \mathrm{MS}$ basal medium]

\section{Discussion}

The genus Colchicum in Turkey has a wide distributional range with 50 species of which 15 are endemic for the country (Dahlgren et al. 1985, Persson 1999a, Akan \& Eker 2005). In addition to the relatively wide distribution range for the genus, Turkey is the richest country in terms of the species diversity. However, in the present study, only 61 C. chalcedonicum, known to be grown on rich red soils at dry stony and rocky places, were found only at Çamlica Hill which is formed from the red, iron-rich Terra Rossa soil (see Fig. 2).

Limited number of experiments were performed about Colchicum tissue culture (Hayashi et al. 1988, Yoshida et al. 1988, Khan et al. 2011, Daradkeh et al. 2012, Wagh et al. 2015). In our sterilization protocol, we used $0.25 \%$ (w/v) $\mathrm{HgCl}_{2}$ for surface sterilization, while Wagh et al. (2015) used $0.15 \%(w / v) \mathrm{HgCl}_{2}$ for surface sterilization of C. luteum Baker corms. The reason for the use of $0.25 \%$ $(\mathrm{w} / \mathrm{v}) \mathrm{HgCl}_{2}$ in our study was that the soil where the corm explants obtained from Çamlica Hill is composed of mineral particles, organic matter, water, air and living organisms.

In our study, we tested different sucrose concentrations $-(3,8$ and $10 \%)$ and $8 \%$ and $10 \%$ resulted with better callus formation. Nagaraju et al. (2002) tested 30, 60, 90 and 120 $\mathrm{g} \mathrm{L}^{-1}$ sucrose concentrations and observed that sucrose showed a significant effect on corm size and weight, leaf 
weight and root length. Additionally, studies revealed that Colchicum corms were more desirable for callus induction (Daradkeh et al. 2012, Wagh et al. 2015). Our study demonstrated that corm was better than leaves and corm shells as an explant for callus development. Callus formation rates for corm were observed around $15 \%$ and $75 \%$ for MS supplemented with NAA $\left(1 \mathrm{mg} \mathrm{ml}^{-1}\right)$, ZEA (1 $\mathrm{mg} \mathrm{ml^{-1 }}$ ) containing $10 \%$ sucrose- and $2^{-1}$ MS supplemented with 2,4 D (2 mg ml$\left.{ }^{-1}\right)$, 2IP $\left(0.5 \mathrm{mg} \mathrm{ml}^{-1}\right)$, $3 \%$ sucrose and $0.05 \%$ active carbon medium, respectively (see Figs 3, 4). However, no callus formation was observed from leaves and corm shells, indicating that they are not suitable for callus formation as explant. Colchicum chalcedonicum is known as a calcitrant species. Because of its advantages, micro-propagation of corm plants could be an alternative to the conventional techniques for vegetative propagation, increasing many times the multiplication level, enabling the plant materials to be freed from diseases especially for medicinal plants (Shibli \& Ajlouni 2000, Chang et al. 2000).

Our efforts are continuing for developing callus formation protocol. Yalcin Mendi et al. (2017) reported micro-propagation of some endemic Colchicum species, but not on tissue culture for $C$. chalcedonicum. However, they used to active carbon to induce callus formation in Colchicum cultures. Active carbon is frequently used in tissue cultures to improve micro-propagation, orchid seed germination, somatic embryogenesis, anther culture, synthetic seed production, protoplast culture, rooting, stem elongation, corm formation etc (Thomas 2008). Studies with activated carbon in tissue culture demonstrated that activated carbon may be provide irreversible adsorption of inhibitory compounds in the culture medium significantly reducing the toxic metabolites, phenolic exudation and brown exudate accumulation (Thomas 2008). In our study, active carbon may enhance callus formation by limiting the brown exudate accumulation. We observed that green and soft callus formation resulted in medium containing active carbon. Also, callus formation in medium containing active carbon was faster than other mediums we tested.

Colchicum species comprise flavonoids, phenolic acids, tannin, fatty acids and colchicine is the major alkaloid isolated from Colchicum species such as $C$. autumnale and C. luteum (Kapadia et al. 1972, Levy et al. 1991, Evans 2002). Studies demonstrated that colchicine possesses antitumoral and anti-inflammatory activity and that it has a great potential for cancer treatment, making derivatives of colchicine, especially demecolcine and trimehyl colchicine acid methyl ester, to be evaluated as anti-cancer agent (Cocco et al. 2010, Bisi et al. 2015). However, no systematic attempt has been performed on micro-propagation for elite genotypes such as "Medicinal Plants" including Colchicum species. Our callus formation protocol has served promising results for future. Hayashi et al. (1988) used IBA and kinetin as PGRs in C. autumnale tissue culture for callus formation, and they managed to obtain colchicine by callus tissue culture system. However, production of secondary metabolites can be achieved by two main groups of in vitro cultures: organized cultures of differentiated tissues (i.e., organ cultures as root, shoot and embryo cultures) and unorganized cultures of undifferentiated cells (i.e., callus and cell suspension cultures). Although organized cultures of differentiated tissues produce the same secondary metabolites as the plant itself, which are relatively more stable than the undifferentiated cells, especially non-embryogenic plant callus cultures are mostly used for production of valuable secondary metabolites, including such as tropane alkaloids, hyoscyamine and scopolamine (Verpoorte et al. 2002, Filova 2014). Our present study is the pioneering study for tissue culture of $C$. chalcedonicum., and tissue culture studies of $C$. chalcedonicum may also be applied for callus formation of important Colchicum species possessing colchicine.

An organism is identified as "endemic" which is native and has a restricted geographical region. Endemic species may be restricted due to physical barriers to dispersion, as in the case of many island faunas and flora, the barriers surround its area of origin, and consequently, they evolve within their limited distributional ranges (Masseti 2009). The extinction of plant and animal species, particularly with the ongoing climate change effects, has become an important issue, especially for endemic species. An alternative method of protection of endemic plant species is producing them via multiplying and conservation of plants by using in vitro culture techniques. The producing of endemic plants using tissue culture systems via multiplying is termed micropropagation which has lots of advantages including high coefficient of multiplying, small needs on number of initial plants, small needs on space and reproducing of plants regardless seasons of the year, through multiplying intervals between subcultures in slow growing species (Kováč 1995, Engelmann 1997, 1998). We aimed to find the best nutrient media, PGRs and explants for micropropagation and in vitro conservation of $C$. chalcedonicum. However, we were able to establish only efficient callus protocol were the pioneering of micropropagation. This callus formation protocol will serve the improvement of tissue culture techniques to obtain more efficient callus formation protocols and to lead the micropropagation of $C$. chalcedonicum in the future.

\section{Conclusion}

The success of efficient callus protocol improvement for in vitro conservation of $C$. chalcedonicum relies on the optimal choice of the explants, on the efficiency of the sterilization method, and on the establishment of an in vitro culture protocol for these calcitrant species for the beginning of aseptic proliferative cultures and on the optimal choice of nutrient media and PGRs. According to our experimental data, the optimal media for efficient callus formation of $C$. chalcedonicum were MS supplemented with NAA (1 mg ml-1), ZEA (1 mg ml-1) containing $10 \%$ sucrose - and 2-1 MS supplemented with 
2,4 D (2 mg ml-1), 2IP (0.5 mg ml-1), 3\% sucrose and $0.05 \%$ active carbon medium. Additionally, supplying of active carbon in the media induced the callus formation. Our work is the pioneering study to obtain sophisticated callus formation protocol for in vitro conservation of $C$. chalcedonicum. Our study may help to save $C$. chalcedonicum which is endemic in İstanbul, Turkey.

\section{References}

1. Akan, H. \& Eker, İ. 2005. Check-list of the genus Colchicum in the flora of Turkey. Turkish Journal of Botany, 29: 327-331.

2. Aznavour, G.Y. 1897. Note sur la flore des environs dc Constantinople. Bulletin de la Société Botanique de France, 44: 164-177.

3. Bisi, A., Gobbi, S., Merolle, L., Farruggia, G., Belluti, F., Rampa, A., Molnar, J., Malucelli, E. \& Cappadone, C. 2015. Design, synthesis and biological profile of new inhibitors of multidrug resistance associated proteins carrying a polycyclic scaffold. European Journal of Medicinal Chemistry, 92: 471-80. https://doi.org/10.1016/j.ejmech.2015.01.004.

4. Brickell, C.D. 1984. Colchicum L, In: Davis PH (ed) Flora of Turkey and the East Aegean Islands. Vol. 8, University Press, Edinburgh.

5. Chang, C., Chen, C.T., Tsai, Y.C. \& Chang, W.C. 2000. A tissue culture protocol for propagation of a rare plant, Lilium speciosum Thunb. var. gloriosoides Baker. Botanical bulletin of Academia Sinica, 41: 139-142. https://doi.org/10.7016/BBAS.200004.0139.

6. Cocco, G., David, C.C. \& Pandolfi, S. 2010. Colchicine in Clinical Medicine. A Guide for Internists. European Journal of Internal Medicine, 21: 503-508. https://doi.org/10.1016/j.ejim.2010.09.010.

7. Combeau, C., Provost, J., Lancelin, F., Tournoux, Y., Prod'homme, F., Herman, F., Lavelle, F., Leboul, J. \& Vuilhorgne, M. 2000. RPR112378 and RPR115781: two representatives of a new family of microtubule assembly inhibitors. Molecular Pharmacology, 57(3): 553-63. https://doi.org/10.1124/mol.57.3.553.

8. Dahlgren, R.M.T., Clifford, H.T. \& Yeo, P.F. 1985. The Families of the Monocotyledons -Structure, Evolution and Taxonomy. Springer-Verlag Berlin Heidelberg, New York.

9. Daradkeh, N.Q., Shibli, R.A., Makhadmeh, I.M., Alali, F. \& Al-Qudah, T.S. 2012. Cell suspension and in vitro production of colchicine in wild Colchicum hierosolymitanum Feib. The Open Conference Proceedings Journal, $\quad 3: \quad 52-59$. https://doi.org/10.2174/1876326X01203020052.

10. Dumontet, C. \& Sikic, B.I. 1999. Mechanisms of action of and resistance to antitubulin agents: microtubule dynamics, drug transport, and cell death. Journal of Clinical Oncology, $17(3)$ : 1061-1070. https://doi.org/10.1200/JCO.1999.17.3.1061.

11. Engelmann, F. 1997. In vitro conservation methods. In: Ford-Lloyd BV, Newburry HJ, Callow JA, (Eds) Biotechnology and plant genetic resources conservation and use. Wallingford: CABI, pp. 119-162.

\section{Acknowledgement}

This study was supported by Kadıköy Municipality (İstanbul-TURKEY). The authors thank Merve Albayrak and Prof., Dr. Neslihan Yesim Yalcin Mendi for sharing their results of studies on Colchicum species. The authors also thank Dr. Stuart James Lucas for his kind revision.

12. Engelmann F. 1998. In vitro conservation of horticultural genetic resources: Review of the state of the art. World Conference on Horticultural Research; 1998. Rome. 17-20.

13. Evans, W.C. 2002. Trease and Evans' Pharmacognosy, WB Saunders, Edinburgh, London.

14. Filova, A. 2014. Production of Secondary Metabolites in Plant Tissue Cultures. Research Journal of Agricultural Science, 46(1): 236-45.

15. Gulsoy-Toplan, G., Göger, F., Yildiz-Peko, A., Gibbons, S., Sariyar, G. \& Mat A. 2018. Chemical Constituents of the Different Parts of Colchicum micranthum and $C$. chalcedonicum and their Cytotoxic Activities. Natural Product Communications, 13:535-538. https://doi.org/10.1177/1934578X1801300506.

16. Hayashi, T., Yoshida, K. \& Sano, K. 1988. Formation of alkaloids in suspension-cultured Colchicum autumnale. Phytochemistry, 27(5): 1371-1374. https://doi.org/10.1016/0031-9422(88)80196-1.

17. Kapadia, V.H., Dev, S., Rao, R.S. \& Ansari, M.Y. 1972. New source of colchicine in Iphigenia. Phytochemistry, 11: 1193.

18. Khan, H., Tariq S.A. \& Khan, M.A. 2011. Biological and phytochemical studies on corms of Colchicum luteum Baker. Journal of Medicinal Plants Research, 5(32):70317035. https://doi.org/10.5897/JMPR11.1159.

19. Kováč, J. 1995. Explantátové kultury rostlin. Skript, UP, Olomouc.

20. Küçüker, O. 1984. Liliaceae (Colchicum) in IOPB chromosome number reports. Taxon, 33: 536.

21. Levy, M., Spino, M. \& Read, S.E. 1991. Colchicine: A State of the Art Review. Pharmacotherapy: The Journal of Human Pharmacology and Drug Therapy, 11: 196-211. https://doi.org/10.1002/j.1875-9114.1991.tb02629.x.

22. Masseti, M. 2009. Protected Areas and Endemic Species. In: Gherardi, F., Corti, C., \& Gualtieri, M. (Eds), Biodiversity Conservation and Habitat Management. Vol. 1, EOLSS Publications, pp. 118-127.

23. Murashige, T. \& Skoog, F. 1962. A revised medium for rapid growth and bioassays with tobacco tissue cultures. Physiologia Plantarum, 15: 473-497. https://doi.org/10.1111/j.1399-3054.1962.tb08052.x.

24. Nagaraju, V., Bhowmik, G. \& Parthasarathy, V. 2002. Effect of paclobutrazol and sucrose on in vitro cormel formation in gladiolus. Acta Botanica Croatica, 61: 27-33.

25. Persson, K. 1988. New Species of Colchicum (Colchicaceae) from the Greek mountains. Wildenowia, 18: 29-46. 
26. Persson, K. 1998. Comments on Some Tesselated Colchicum Species in the East Mediterranean area. Candollea, 53(2): 399-417.

27. Persson, K. 1999a. The Genus Colchicum in Turkey I. New Species. Edinburgh Journal of Botany, 56(1): 85-102. https://doi.org/10.1017/S0960428600002390.

28. Persson, K. 1999b. The Genus Colchicum in Turkey II. Revision of the Large-Leaved Autumnal Species. Edinburgh Journal of Botany, 56(1): 103-142. https://doi.org/10.1017/S0960428600002407.

29. Persson, K. 1999c. New and Revised Species Colchicum L. (Colchicaceae) from the Balkan Peninsula. Plant Systematics and Evolution, 217: 55-80. https://doi.org/10.1007/BF00984922.

30. Persson, K. 2000. Colchicum L. In: Güner, A. (Ed) Flora of Turkey and the East Aegean Islands. Vol. 11. University Press, Edinburg.

31. Persson, K. 2001. A New Soboliferous Species of Colchicum in Turkey. Botanical Journal of the Linnean Society, 135: 85-88. https://doi.org/10.1006/boj1.2000.0384.

32. Persson, K. 2007. Nomenclatural synopsis of the genus Colchicum (Colchicaceae), with some new species and combinations. Botanische Jahrbücher für Systematik, 127: 165-242. https://doi.org/10.1127/0006-8152/2007/0127016.

33. Pirildar, S., Sutlupinar, N., Atasever, B., Erdem Kuruca, S., Papouskova, B. \& Śimánek, V. 2010. Chemical constituents of the different parts of Colchicum baytopiorum and their cytotoxic activities on K562 and
HL60 cell lines. Pharmaceutical Biology, 48(1): 32-39. https://doi.org/10.3109/13880200903029373.

34. Shibli, R.A. \& Ajlouni, M.M. 2000. Somatic embryogenesis in the endemic black iris. Plant Cell, Tissue and Organ Culture, 61: 15-21. https://doi.org/10.1023/A:1006468122819.

35. The Wealth of India. 1962. A dictionary of Indian raw materials, Vol. VI., C.S.I.R New Delhi, India, 1962

36. Thomas, T.D. 2008. The role of activated charcoal in plant tissue culture. Biotechnology Advances, 26: 618-631. https://doi.org/10.1016/j.biotechadv.2008.08.003.

37. Verpoorte, R., Contin, A. \& Memelink, J. 2002. Biotechnology for the Production of Plant Secondary Metabolites. Phytochemistry Reviews, 1: 13-25. https://doi.org/10.1023/A:1015871916833.

38. Wagh, P.J., Patil, V.W. \& Kale, M.C. 2015. Effect of Soluble Chitosan Application on in vitro Germination and Growth of Dormant Corms of Colchicum Luteum Baker. International Journal of Researches in Biosciences, Agriculture and Technology, 3:179-182.

39. Yalçin Mendi, N.Y., Özkaya, A., Sari, M., Özdemir, M.Ş., Sevindik, B., Şimşek, O. \& et al, 2017. Somatic embryogenesis of some Colchicum species. Paper presented at International Molecular Biology and Biotechnology Congress, 22-25 December 2017, Afyon, Turkey.

40. Yoshida, K., Hayashi, T. \& Sano, K. 1988. Colchicine precursors and the formation of alkaloids in suspensioncultured Colchicum autumnale. Phytochemistry, 27: 13751378. https://doi.org/10.1016/0031-9422(88)80197-3. 